\title{
Phonological phrase boundary and word frequency that influence the phonological word recognition*
}

\author{
Jeahong $\mathrm{Kim}^{1} \cdot$ Hasun $\mathrm{Shin}^{1} \cdot$ Yeseul $\mathrm{Kim}^{2} \cdot$ Gwangyeol Yun ${ }^{2} \cdot$ Daseul Kim$^{2} \cdot$ Jiyoung Shin $^{2 * *} \cdot$ Kichun Nam $^{1 * * *}$ \\ ${ }^{1}$ Department of Psychology, Korea University, Seoul, Korea \\ ${ }^{2}$ Department of Korean Language and Literature, Korea University, Seoul, Korea
}

\begin{abstract}
This study investigated the interaction between phonological phrase boundary and word frequency variable in Korean speech processing. A word monitoring task was performed to examine the interference caused by the frequency effect of target word depending on whether a phonological phrase is formed within the target word. Frequency of target word (high vs low) and phonological phrase boundary (within target word vs between target words) were applied as between and within subject condition respectively. Our results showed the significant main effect of the phonological phrase boundary and the significant interaction. In the post-hoc analysis, the high-frequency target words were detected significantly faster than the low-frequency target words only in the within phonological phrase boundary condition. Frequency effect in the between phonological phrase boundary condition did not appear. The results indicated that the phonological phrase boundary and word frequency variable played an important role in Korean speech processing. In particular, we discussed the possibility of processing the word frequency at the very early sensory information processing stage based on the interaction of two experimental factors.
\end{abstract}

Keywords: phonological word recognition, phonological phrase, frequency effect

\section{1. 서론}

말소리에는 분절음적(segmental) 정보와 함께 운율적(prosodic) 정보도 함께 포함되어 전달된다. 따라서 복합적인 정보로 구성 된 말소리 문장을 이해할 때 어떤 정보가 우선 작용하는지를 알
아보는 것은 매우 흥미로운 연구 주제이다. 본 연구의 목적은 연속된 발화에 포함된 음운단어(phonological word) 재인 시 운 율정보와 어휘정보 사이의 상호작용 양상을 살펴보는 것이다.

문어와 구어는 서로 다른 특징을 가지고 있다. 문어는 띄어쓰 기가 단어와 단어의 경계를 명확히 구분하지만, 구어는 단어와

\footnotetext{
* This research was supported by the MSIT (Ministry of Science and ICT), Korea, under the ITRC (Information Technology Research Center) support program (IITP-2019-2017-0-01630) supervised by the IITP (Institute for Information \& Communications Technology Promotion).

**shinjy@korea.ac.kr, Corresponding author

***kichun@korea.ac.kr, Corresponding author

Received 7 May 2019; Revised 5 June 2019; Accepted 14 June 2019

(c) Copyright 2019 Korean Society of Speech Sciences. This is an Open-Access article distributed under the terms of the Creative Commons Attribution NonCommercial License (http://creativecommons.org/licenses/by-nc/4.0) which permits unrestricted non-commercial use, distribution, and reproduction in any medium, provided the original work is properly cited.
} 
단어의 경계가 명확하게 나뉘지 않는다. 선행연구를 통해 사 람이 말소리에서 단어와 단어의 경계를 찾도록 돕는 단서로 말소리의 운율정보를 사용하고 있다는 것을 확인할 수 있다 (Christophe et al., 2004; Cutler \& Norris, 1988; Gout et al., 2004; Jusczyk et al., 1999; Nazzi et al., 2006). Christophe et al.(2004)은 프 랑스어 화자가 음운구(phonological phrase)의 경계에 따라 단어 를 분절한다는 것을 확인하였다. 이 연구에 따르면 프랑스어 화 자들의 경우, 음운구 경계와 단어 경계가 일치할 때(예, [son grand chat] [grimpait]의 'chat' 과 'grim')가 음운구 경계와 단어 경 계가 일치하지 않을 때(예, [un chat grincheus]의 'chat'과 'grin')보 다 단어를 쉽게 분절하는 것으로 나타났다.

한국어 말소리 처리에도 음운구의 경계는 중요한 단위로 알려 져 있다(Shin, 2011). 한국어를 대상으로 연구한 Kim \& Cho(2009) 는 음운구 경계의 마지막 음절이 갖는 성조와 다음 음운구 경계 의 첫 번째 음절의 성조가 두 음운구의 경계를 찾고 단어를 분 절하는 데에 이용된다고 주장하였다. Choi et al.(2011) 역시 음운 구 경계가 한국어 음운단어 탐색에 중요한 요인으로 작용함을 한국인 화자를 통한 실험으로 밝혀냈다. Choi et al.(2011)의 단 어찾기과제(Word-Monitoring Task)에서는 ‘[방수 비늘로] [만든] [가방이다].' '에서 '수비'를 찾아내는 시간이 '[사방에서] [예찬 이] [쏟아졌다].'에서 '서예'를 찾아내는 시간보다 유의미하게 빠른 것을 확인하였다. 한편, 음절찾기과제에서는 '[방수 비늘 로] [만든] [가방이다].'에서 '비'를 찾는 시간이 '[사방에서] [예 찬이] [쏟아졌다].'에서 '예'를 찾는 시간보다 느리게 나타난 것 을 확인하였다. 이 결과를 통해 음운구 경계의 존재가 목표단어 를 찾는 데에는 방해효과를, 음절을 탐지하는 데에는 촉진효과 를 일으킨 것을 확인할 수 있다.

선행연구 검토를 통해 음운구 경계가 발화에서 단어를 분절 하고 음운단어를 재인하는 데 중요한 역할을 차지한다는 것을 알 수 있다. 한국어는 음운구 형성 여부에 따라 음높이 변화 양 상이 달라지는 특징을 갖는다(Shin, 2011). 즉, 두 개의 음운단어 가 두 개의 음운구로 실현될 땐 첫 음운단어의 마지막 음절과 두 번째 음운단어의 첫 번째 음절의 음높이 차이가 크지만, 하나의 음운구로 실현될 때 두 음절의 음높이가 완만하게 연속적으로 떨어지는 특징을 갖는다. 결국, 소리지각 단계에 물리적 특성이 있는 음운구 경계가 청각 단어재인에 영향을 미치는 것이다. 문 장 자극을 사용한 뇌파 연구(Männel \& Friederici, 2009)와 음악을 사용한 뇌파 연구(Nan et al., 2009)에서 목표자극 제시 이후 200 $\mathrm{ms}$ 시간대의 P2 컴포넌트가 운율 경계에 민감하다는 결과 또한 운율 단위에 속하는 음운구 경계가 청각 단어재인의 초기의 물 리적 특성과 연관이 있다는 점을 뒷받침하는 것으로 해석할 수 있다.

한편, 출현 빈도가 높은 단어가 낮은 단어에 비해 처리 속도 가 빠르다는 빈도효과(frequency effect)의 확인은 언어심리학 분
야에서 지속적으로 이루어졌다. 단어 검출기 모델들(word detector models)로 알려진 로고젠 모델(Morton, 1969), 상호 작용적 활성 화 모델(interactive activation model; McClelland \& Rumelhart, 1981) 이나 연속 검색 모델(serial search model; Rubenstein et al., 1970; Forster, 1976) 그리고 활성/검증 모델(activation/verification model; Schvaneveldt \& McDonald, 1981)에서 고빈도 단어의 재인이 저빈 도 단어의 재인보다 빠른 이유를 탐색기의 역치(threshold)나 기 본 활성화 값(activation strength)의 차이 등으로 설명하고 있다 (Monsell, 2012 참고).

대표적인 어휘 변인인 빈도는 어휘접속에 결정적인 역할을 할 것으로 예상할 수 있지만, 오히려 어휘접속 전의 단어재인 초 기처리단계에 영향을 미친다는 주장이 있다. 시각 단어재인 연 구에서 어휘 변인들의 처리 시간대를 알아본 Hauk et al.(2006)은 빈도효과가 $110 \mathrm{~ms}$ 시간대에 나타난다고 보고함으로써, 빈도가 시각단어 처리에서 매우 이른 시간대에 처리될 수 있다고 주장 하였다. 정보가 병렬적으로 들어올 수 있는 시각단어재인의 경 우에는 단어의 빈도가 초기에 영향을 미칠 수 있다는 주장은 타 당성이 높은 것으로 보인다.

시각단어와는 달리 청각단어는 순차적으로 정보가 입력될 수 밖에 없다는 점에서 시각단어의 정보처리와 다른 양상을 보일 것으로 예상된다. 대표적으로 후기 TRACE 모델(McClelland \& Elman, 1986)은 말소리의 순차적인 활성화 처리과정이 음향적 자 극(phenetic features), 음소(phonemes) 그리고 단어의 순서를 거친 다고 설명한다. 이 모델에 따르면 청각단어재인 시 어휘변인과 관련이 깊은 단어빈도가 재인의 초기단계에 영향을 미칠 가능 성은 낮다고 예상할 수 있다. 하지만 Dahan et al.(2001)은 고빈도 단어와 저빈도 단어에 해당하는 그림을 주시하는 시간을 측정 한 안구운동 연구를 통해 고빈도 단어에 해당하는 그림에 시선 을 두는 시간(fixation latency)이 저빈도 단어에 해당하는 그림에 시선을 두는 시간보다 더 길다는 것을 관찰하였다. 그리고 그 결과를 바탕으로 빈도효과가 단어재인의 초기처리단계에 영향 을 미치는 것을 주장하였다2.

이러한 맥락에서 단어재인 시 중요한 역할을 하는 빈도효과 와 한국어의 음성언어 처리에서 중요한 역할을 하는 것으로 보 이는 음운구 경계 효과 사이의 상호작용을 조사하는 것은 흥미 로운 일이 될 것이다. 실험을 통해 한국어의 음성언어 처리 과 정에서 보이는 운율 단위 구성 정보와 어휘 정보의 상대적 중요 성을 확인할 수 있을 것으로 기대되기 때문이다. 음운구 경계는 물리적인 특성에 기반하는 반면에 빈도효과는 어휘적 특성에 기반하므로, 물리적 특성에 기반하는 경계 정보가 청각단어재인 에 더 큰 영향을 미칠 것으로 예상해 볼 수 있다. 이를 확인하기 위해 본 연구에서는 단어찾기과제(word monitoring task)(Christophe et al., 2004; Cutler \& Foss, 1977; Ralston et al., 1991; Shields et al., 1974; Tyler, 1989; Tyler \& Warren, 1987)를 음운구 경계 유무 환

1 음운구 단위를 각괄호([ ])로 표시함.

2 Balota \& Chumbley(1984; 1985), Connine et al.(1993)의 빈도효과가 이른 시간에 처리된다는 주장을 반대한 논문도 참고할 필요가 있다. 
경과 고빈도와 저빈도 환경에서 수행하게 함으로써 각 환경에 서 한국어 모국어 화자들이 보이는 반응시간 차이를 비교하였 다. 음성언어 처리 과제에서 생기는 특성을 고려하여 관련 변수 를 철저히 통제하고자 노력하였다.

\section{2. 연구방법}

\section{1. 실험참가자}

대학교 학부 혹은 대학원에 재학 중인 다양한 전공의 학생들 을 대상으로, 청력에 이상이 없으며 한국어를 모국어로 사용하 는 성인 남녀 58명이 실험에 참여하였다. 29명(남 14명, 여 15명) 은 음운구 경계 내(이하 경계 내) 집단에 할당되었고, 나머지 29 명(남 13 명, 여 16 명)은 음운구 경계 간(이하 경계 간) 집단에 할 당되었다.

\section{2. 실험 자극}

실험에 사용된 문장은 총 90 개로 그중 60 개의 문장이 목표단 어를 포함하고 있는 실험 자극과 통제자극으로 사용되었고, 나 머지 30 개의 문장이 목표단어를 포함하지 않은 방해자극으로 사용되었다. 단어탐지과제에서 문장을 듣는 동안 60 개의 목표 단어를 포함한 문장에는 목표단어를 찾아 ‘있다'라고 반응해야 했으며, 30 개의 방해자극 문장에는 ‘없다'라고 반응해야 했다.

60 개의 목표단어를 포함하고 있는 문장 중 40 개의 실험자극 은 국지적 어휘 중의성 3 이 발생하는 조건으로 각각 20 개씩의 고 빈도와 저빈도 목표단어 자극으로 구성되었으며, 각각 목표단 어의 위치가 음운구 경계에 걸치게 녹음된 문장을 음운구 경계 간 조건, 걸치지 않게 녹음된 문장을 음운구 경계 간 조건으로 배정하여 참가자간 변인으로 사용하였다. 20 개의 통제자극은 국지적 어휘 중의성이 없는 자극으로 실험자극이 가지는 음운 구 경계 방해효과를 비교하기 위해 구성되었다.

실험 자극에 사용된 목표단어는 세종 현대문어 형태분석 말 뭉치 1,500 만 어절에서 선정된 외래어를 제외한 고유어, 한자어 2음절 명사이다. 고빈도 단어는 $26 \mathrm{mil}$ 이상, 저빈도 단어는 $9 \mathrm{mil}$
미만인 것 중 선정하였다. 목표단어4는 시각 정보로 주어지고, 목표단어가 들어간 문장은 청각 정보로 주어지는 실험인 만큼, 목표단어는 철자와 발음이 항상 일치하는 것으로만 선정하였 다. 한국어는 음운구 내에서 장애음과 평 장애음의 연쇄, 장애음 과/히의 연쇄를 허용하지 않아 경음화, 격음화 등의 음운 현상 이 일어난다. 또한, 수의적으로 후행하는 소리에 선행하는 소리 가 동화되는 조음 위치 동화현상이 일어난다. 따라서 예를 들어, 격음화가 일어나는 ‘약효', 조음 위치 동화가 일어나는 '선배'는 목표단어로 선정하지 않았다.

이렇게 선정된 목표단어를 이용하여 자극 문장을 생성하였 는데, 자극 문장은 음운구 경계를 넣어 발화한 것을 기준으로, 4 개의 음운구로 산출되는 것이 자연스럽고, 음운구 경계를 넣지 않아도 자연스럽도록 생성하였다. 말소리 과제에서 생기는 특 성을 자세히 통제하고자 노력하였는데, 먼저 목표단어 선정 시 와 동일하게, 외래어는 제외하였다. 목표단어의 앞 뒤 음절에서 도 음운 변동이 일어나지 않도록 하여 음운동화 효과를 통제하 였다. 목표단어의 위치에 대한 변인도 통제하기 위해, 목표단어 는 목표단어의 각 음절 사이에 음운구 경계가 있는 발화를 기준 으로 4 개의 음운구 위치에 골고루 들어가도록 했다. 한국어 표 준어에서 음운구의 두 번째 음절과 마지막 음절은 전형적으로 고성조로 실현된다(Shin, 2011). 고성조 음절은 저성조 음절보다 청각적으로 두드러지므로, 목표단어를 확인할 때 목표단어의 첫음절의 성조가 조건별로 다를 시, 참가자의 반응시간에 영향 을 줄 것으로 판단할 가능성이 있다. 따라서 본 실험은 목표단어 의 첫 번째 음절은 각각의 음운구 경계 간 조건과 음운구 경계 내 조건의 음운구 내 두 번째 음절에 위치하도록 조작하여 조건 간의 성조가 모두 고성조로 실현되도록 하였다(표 1. 예시 참고). 마지막으로 목표단어의 각 음절은 어휘형태소의 일부가 되도 록 하였다. Bell et al.(2009)에 따르면 단어 빈도가 내용어(content word)에만 영향을 미치며 기능어(function word)에는 영향을 미 치지 않았기 때문이다.

자극으로 생성된 문장은 한국어 교육학 전공 석사 과정생 20 대 여성 표준어 화자가 소음이 통제된 환경에서 녹음하였다.

표 1. 실험에 사용된 자극 조건 및 예문

Table 1. Examples of experimental stimuli

\begin{tabular}{|c|c|c|c|c|}
\hline 자극종류 & 음운구 경계 조건 & 빈도 조건 & 예시 문장 & 목표단어 \\
\hline \multirow{4}{*}{ 실험 자극 } & \multirow{2}{*}{$\begin{array}{c}\text { 음운구 경 계 내 } \\
\text { (40개 자극) }\end{array}$} & 고빈도 & [이사회의] [반대 표명이] [있었다]. & 대표 \\
\hline & & 저빈도 & [세 뱃돈은] [항상] [우리] [엄마 차지 였다]. & 마차 \\
\hline & \multirow{2}{*}{$\begin{array}{c}\text { 음운구 경계 간 } \\
\text { (40개 자극) }\end{array}$} & 고빈도 & [이사회의] [반대] [표명이] [있었다]. & 대표 \\
\hline & & 저빈도 & [세 뱃돈은] [항상] [우리 엄마] [차지였다]. & 마차 \\
\hline 통제 자극 & $\begin{array}{c}\text { 음운구 내 단어 } \\
\text { (20개 자극) }\end{array}$ & & [경포 바다를] [보며] [숼 수 있는] [펜션이다]. & 바다 \\
\hline 방해 자극 & $\begin{array}{c}- \\
\text { (30개 자극) }\end{array}$ & & 연구를 하는 것에 매진하고 있다. & 소리 \\
\hline
\end{tabular}

주. [] 는 음운구 경계를 의미함.

3 Choi et al.(2011)은 말소리 이해 과정에서 분절이 제대로 이뤄지지 않을 경우 발생하는 중의성을 국지적 어휘 중의성이라 명명하였다. 본 연구에서 도 이 용어를 사용한다.

4 고빈도(평균: 114.50 , 표준오차: 19.20)와 저빈도(평균: 6.54, 표준오차: 0.23 ) 자극의 빈도는 유의미한 차이가 있었으며 $[t(1,19)=5.988, p=0.000]$, 첫 음절과 두 번째 음절의 빈도는 유의미한 차이가 없었다[첫 음절: $t(1,19)=0.013, p=0.990$, 두 번째 음절: $t(1,19)=1.188, p=0.249]$. 
$44,100 \mathrm{~Hz}$ 의 표본추출률에 모노 타입으로 녹음하였으며, $16 \mathrm{bit}$ 로 양자화하였다. 모든 문장 내에는 억양구 경계가 없도록 녹음 하였다. 녹음된 문장은 국어 음성학 전공의 박사 수료생 2 명과 박사 과정생 1 명, 총 3 명의 전문가의 평정을 받았다. 평정 항목 은 목표단어 내의 음운구 경계 및 억양구 경계 존재 여부와 문 장의 전체적인 운율이 자연스러운지의 3 가지였고, 2 회에 걸쳐 평정을 받은 후, 2 명 이상이 문제없는 자극이라고 판단한 것만 을 사용하였다. 평정을 마친 녹음은 Praat 6.0 .40 의 modify 기능 으로 평균 강도(average intensity)가 $70 \mathrm{~dB} \mathrm{SPL}$ 이 되도록 조정하 였다.

\section{3. 실험 설계 및 분석}

실험은 $2 \times 2$ 혼합 설계(mixed design)로 구성되었다. 집단 내 변 인은 목표단어의 빈도로, 고빈도와 저빈도 조건을 설정하였다. 집단 간 변인은 경계 종류로, 목표단어가 속한 어절들이 1 개의 음운구로 발화된 음운구 경계 내 그리고 목표단어가 속한 어절들 이 2 개의 음운구로 발화된 음운구 경계 간 조건을 설정하였다.

본 연구에서는 문장 내의 다양한 위치에 목표단어가 등장하 기 때문에, 실험참가자의 정확한 반응시간을 측정하기 위해서 문장 내의 목표단어 첫 음절의 시작 시간을 측정하는 작업이 필 요하였다. 목표단어 첫 음절의 시작 시간 측정은 Lee et al.(2003) 의 레이블링 기준안을 참고하여 본 연구에 맞게 몇 가지 기준을 세우고 실시하였다.

목표단어 첫 음절의 시작점 측정은 청지각적 판단을 우선으 로 하고, 스펙트로그램(spectrogram)을 통해 선행 음절의 끝점을 확인한 후, 목표하는 음절의 시작점을 표시는 방법으로 진행하 였다. 청지각적 판단이 어려운 경우, 몇 가지 기준을 통해서 측 정이 일관되게 이루어질 수 있도록 통제하였다. 먼저, 모음의 분 절은 선행 음소가 자음인 경우는 모음의 포만트(formant)가 시 작되는 부분을 모음의 시작점으로 하였고, 선행 음소가 모음인 경우는 포만트 전이의 중간을 모음의 시작점으로 하였다.

자음의 경우 청지각적 판단만으로 측정이 어려운 것들이 있 었는데, 이는 다음과 같은 기준을 선정한 후 일관되게 측정하였 다. 먼저, 폐쇄 구간을 포함하는 폐쇄음과 파찰음은 어두에 나타 날 경우 폐쇄 구간을 측정하는 것이 어려운데, 본 연구에서는 어두 폐쇄음, 파찰음의 파열 신호가 처음 나타나는 지점의 30 $\mathrm{ms}$ 앞을 해당 음절의 시작시간으로 하였다. 또한, 두 비음이 연 속으로 나타나는 경우, 스펙트로그램 상에서 확실한 구분이 보 이면 그 점을 기준으로 나누었고, 구분이 명확하지 않은 경우 전 체 비음 구간을 반으로 나누어 음절의 시작을 측정하였다.

실험의 통계분석엔 $2 \times 2$ 혼합 설계 반복측정 분산분석(mixedrepeated ANOVA)를 실시하였다. 독립변인으로는 빈도 2수준과 (고 vs. 저) 음운구 경계 2수준이(경계 내 vs. 경계 간) 사용되었고, 종속 변인으로는 각 실험 조건에 대한 반응시간에서 통제 조건 에 대한 반응시간을 뺀 경계 방해 효과 값(표 1 의 방해 효과 값 참고)이 사용되었다. 상호작용을 해석하기 위해 사후검증도 시 행하였다.

\section{4. 실험 절차}

모든 실험참가자들은 고려대학교 심리학과 인지지각실험실 에 마련된 방음실에서 동일한 조건 하에 단어탐지과제를 수행 하였다. PsychoPy 1.90.2를 이용하여 지각 실험을 구성하였고, 실험에 사용된 헤드폰은 SHURE사의 SRH440이었다. 실험 전에 는 실험에 대한 간단한 설명 후, 실험 동의서를 작성하도록 하 였다.

실험의 구성은 다음과 같다. 먼저, 중앙에 + 표시로 응시점을 제시하고, 목표단어가 중앙에 2초 동안 제시된다. 실험 문장이 제시되기 전 추가로 빈 화면이 0.5 초 동안 제시된 후 실험참가자 가 헤드폰을 통해 실험 문장을 듣고, 실험 문장에서 앞서 제시 된 목표단어를 인지하면, 언제든지 가능한 빠르고 정확하게 반 응 버튼을 누르도록 지시하였다.

본 실험에 앞서 연습시행을 실시하였고, 연습시행에서 $80 \%$ 이상의 정확도를 보일 때까지 반복한 후 본 실험을 진행하였다. 연습시행과 본 실험에서 모두, 실험 자극에 관련된 구 경계, 단 어 경계, 단어의 빈도 등은 일절 언급되지 않았다.

본 실험에서는 연구자의 개입을 최소화하기 위해 연구자의 감독 없이 실험참가자가 단독으로 실험을 진행하였다. 실험에 소요된 시간은 실험참가자 1 인당 약 15 분 정도였으며, 실험이 끝난 후 실험참가자에게 소정의 사례비를 지급하였다.

\section{3. 실험 결과}

반응시간은 녹음된 문장 내 목표단어의 첫 음절이 제시된 때 부터 실험참가자가 버튼을 누른 시간까지로 측정하였다. 반응 시간이 3 표준편차를 넘어가면 참가자의 부주의에 의한 반응으 로 간주하여 분석에서 제외하였다. 실험 분석엔 틀린 반응을 제 외한 올바른 반응의 평균 반응시간만 사용하였다. 모든 실험참 가자의 정답률은 $95 \%$ 이상이었으며, 실험 조건 및 통제 조건에 해당하는 자극의 정답률도 $95 \%$ 이상이었다. 각 조건의 평균 반 응시간과 표준오차는 표 2에 제시되어 있다. 또한, 음운구 경계 변인이 집단 간 변인으로 설정되었기 때문에, 각 집단 내 변인 인 고빈도 조건과 저빈도 조건의 반응시간을 통제 조건에서 뺀 방해효과를 계산하여 실험의 종속 변인으로 사용하였다. 방해 효과가 크다는 것은 통제 조건보다 실험 조건에 대한 반응시간 이 더 길었다는 것을 의미한다. 
표 2. 각 조건에서의 평균 반응시간(ms)과 정답률 $(\%)$

Table 2. Mean reaction time (ms) and correct rate (\%)

\begin{tabular}{l|c|c}
\hline \multicolumn{1}{c|}{ 조건 } & 평균 반응시간 & 정답률 \\
\hline 음운구 경계 내 & & \\
\hline 고빈도 & $1,452(96)$ & 96.3 \\
저빈도 & $1,551(99)$ & 95.4 \\
통제 조건 & $1,434(130)$ & 98.5 \\
고빈도 경계 내 방해 효과 & $17(43)$ & -2.2 \\
저빈도 경계 내 방해 효과 & $117(58)$ & -3.1 \\
\hline 음운구경계 간 & & \\
\hline 고빈도 & $1,358(105)$ & 96.7 \\
저빈도 & $1,323(95)$ & 98.7 \\
통제 조건 & $1,154(113)$ & 98.5 \\
고빈도 경계 간 방해 효과 & $204(31)$ & -1.8 \\
저빈도 경계 간 방해 효과 & $170(39)$ & +0.2 \\
\hline 주 괄호 안은 표준편차
\end{tabular}

방해효과에 대한 피험자 분석 결과, 빈도 조건의 유의미한 주 효과는 나타나지 않았지만 $(\mathrm{F} 1[1,56]=2.36, \mathrm{p}=0.132, \eta 2=0.040)$, 음운구 경계 변인의 주 효과가 유의미하게 나타났으며(F1[1, 56]= $4.305, \mathrm{p}=0.043, \eta 2=0.071)$, 상호작용이 통계적으로 유의미하게 나타났다 $(\mathrm{F} 1[1,56]=10.116, \mathrm{p}=0.002, \mathrm{\eta} 2=0.153)$.

상호작용을 해석하기 위해 사후검증을 시행한 결과, 음운구 경계 내에서 빈도효과의 유의미한 차이가 나타나 $(\mathrm{t} 1[1,28]=3.020$, $\mathrm{p}=0.005$ ) 고빈도 조건을 저빈도 조건보다 유의미하게 빠르게 처 리하는 것을 알 수 있었으며, 고빈도 목표단어에서 음운구 경계 에 따른 방해 효과가 나타나 $(\mathrm{t} 1[1,56]=3.550, \mathrm{p}=0.001)$ 음운구 경 계 내 집단이 음운구 경계 간 집단보다 목표단어의 탐색을 빠르 게 한 것을 알 수 있었다(그림 1 참고).

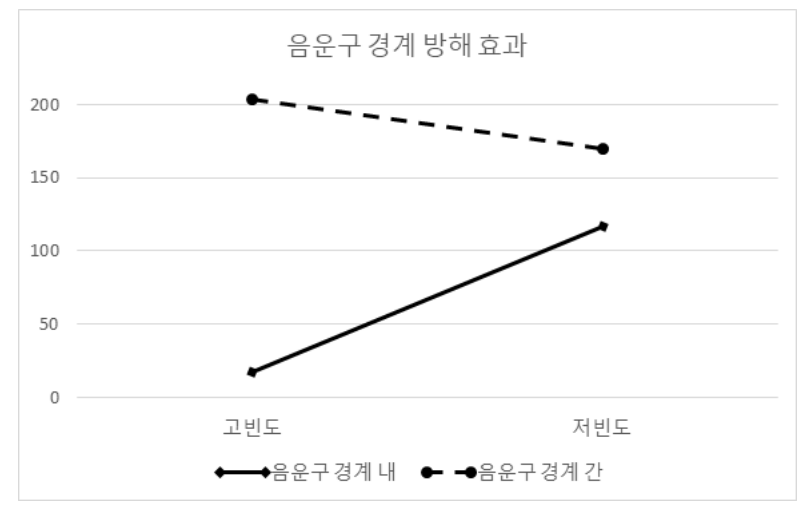

그림 1. 조건별 음운구 경계 방해효과

Figure 1. Interference effect for each condition

\section{4. 논의}

본 연구는 한국어 말소리 분절 정보로 알려진 음운구 경계를 사용해 단어를 탐지할 때, 단어의 빈도가 영향을 미치는지를 알 아보기 위해 수행되었다. 연구의 의미 있는 결과로 음운구 경계 조건과 빈도 조건 간에 유의미한 상호작용 효과가 나타났다. 사 후검증을 통해 상대적으로 단어탐지가 쉬울 것으로 예상하였
던 음운구 경계 내 조건에서만 고빈도 단어의 처리가, 저빈도 단 어의 처리보다 빠르게 나타나는 단어빈도효과를 발견할 수 있 었다. 주 효과는 음운구 경계 변인가 유의미한 주 효과가 있는 것으로 나타났다.

본 연구에서 나타난 두 변인의 상호작용은 음운구 경계 요인 과 빈도 변인이 말소리 분절에 중요한 역할을 한다는 점을 시사 한다. Choi et al.(2011)은 음운구 경계가 말소리 분절에 중요한 역할을 한다고 주장하였는데, 그들은 실험에 고빈도의 음운단 어를 목표단어로 사용하였다. 이는 고빈도 조건에서 음운구 경 계 내의 조건의 방해효과가 유의미하게 적었던 본 실험의 결과 와 일치한다. 즉 음운구 경계가 말소리 분절에 중요한 역할을 한 다는 사실이 재입증된 것이다. 비록 상호작용 효과는 두 변인의 주 효과에 대한 설명을 약하게 만들지만, 음운구 경계 변인의 주 효과가 유의미했던 것과 모든 빈도 조건에서 음운구 경계 내 조건이 더 작은 방해효과를 나타낸 것은 음운구 변인이 빈도 변 인보다 말소리 분절에 상대적으로 더 중요한 역할을 하는 것을 유추할 수 있게 한다. 만약 빈도요인이 더 큰 영향을 미친다면, 모든 음운구 경계 조건에서 고빈도를 저빈도보다 유의미하게 빠르게 처리해야 했으며 고빈도 조건에만 음운구 경계 조건의 차이가 나타나고 저빈도 조건에서는 음운구 경계 조건의 차이 가 없었어야 빈도 요인이 더 큰 영향이 미친 것으로 유추할 수 있다. 두 변인의 말소리 분절에 대한 더 깊이 있는 해석을 위해 Choi et al.(2011)의 실험 2와 같이 음절찾기 과제와 같은 추가적 인 실험을 통한 검증이 필요하다.

빈도 조건과 음운구 경계의 상호작용은 말소리 분절에서 인 지부하 때문에 발생하는 것으로 생각할 수 있다. 본 연구 결과는 음운구 경계 내 조건에서만 빈도효과가 나타났고, 음운구 경계 간 조건에서는 빈도효과가 나타나지 않았다. 또한, 고빈도 목표 단어에서는 음운구 경계효과가 나타났으며, 저빈도 목표단어 에서는 나타나지 않았다. 순차적으로 입력되는 정보를 단기기 억 시스템에 유지하면서 다음 정보를 처리해야 하는 말소리 처 리 과정은 그 자체가 상당한 인지부하를 일으킬 수 있으므로, 음운구 경계에 포함되어 있지 않거나 저빈도 단어를 처리해야 할 때 발생하는 더 큰 처리 부담이 단어재인을 어렵게 만든 것 으로 유추할 수 있다. 말소리 분절에는 음운구 경계와 빈도가 상 대적으로 인지부하가 적은 상황, 즉 고빈도 혹은 음운구 경계 내 조건에서 중요한 역할을 하는 것으로 보인다.

마지막으로 상호작용 효과는 두 변인인 음운구 경계와 빈도 가 말소리 처리의 각각 다른 단계에 영향을 미치는 것이 아니라 같은 단계에서 영향을 미치고 있음을 알려준다. 소리 자체의 특 성과 관련된 음운구 경계 정보는 감각 정보로 말소리 처리과정 초기에 이루어질 가능성이 있으며, 어휘적 특성에 속하는 빈도 는 감각 정보 처리 이후에 처리될 것으로 예상할 수 있다. 하지 만 본 연구의 결과는 두 변인이 서로 다른 층위가 아니라 비슷 한 층위에서 처리될 가능성을 제시한다.

빈도는 소리의 조합(Jescheniak \& Levelt, 1994)부터 형태소, 단어(Monsell et al., 1989) 그리고 통사의 구성(Frazier \& Fodor, 1978)까지 언어처리 전반에 강력한 영향을 미치는 것으로 알려 
진 어휘변인이다. 이런 빈도의 처리는 어휘접속 전부터 후까지 다양한 시간대에서 일어나는 것으로 뇌파 연구를 통해서 밝혀 진 바 있다(Assadollahi \& Pulvermuller, 2001; 2003; Hauk \& Pulvermuller, 2004; Polich \& Donchin, 1988; Rugg, 1990; Sereno et al., 1998; Smith \& Halgren, 1987; Van Petten \& Kutas, 1990). 이 중 Assadollahi \& Pulvermuller(2001)와 Hauk \& Pulvermuller(2004) 의 연구는 단어의 빈도가 처리되는 시간대가 어휘접속 전인 150 200 ms 때부터 나타난다고 보고하여 빈도 처리가 단어재인 의 아주 이른 시간에 처리될 수 있음을 시사하였다. 본 연구의 결과는 이보다 더 이른 초기의 감각 정보 처리 층위에서 빈도가 영향을 미칠 가능성을 제시하는데 더 정확한 시간대를 알아보 기 위해선 추가 뇌파 연구가 필요하다.

각각의 음운구 경계 내 그룹과 음운구 경계 간 그룹의 절대적 인 반응시간은 오히려 음운구 경계 내 조건이 더 느렸다. 이는 두 조건이 그룹 간 변인으로 지정되면서 단어탐지 과제 자체가 가지는 난이도 차이 때문으로 보인다. 실제 분석 결과 실험 조 건과 통제 조건의 명확한 구분이 가능했던 음운구 경계 간 조건 의 반응시간이 전체적으로 더 빨랐던 것을 알 수 있었다. 이런 그룹 간 변인으로 인해 나타나는 차이를 줄이기 위해서 앞서 실 험 자극에서 기술한 것과 같이 통제 자극을 추가하여 조건들의 상대적 효과를 계산하였다.

종합하면, 본 연구의 결과를 통해 한국인이 한국어 말소리를 처리할 때 분절 정보가 포함된 운율 단위인 음운구 경계 정보와 어휘 변인인 빈도 정보를 동시에 사용한다는 것을 알 수 있었다. 특히 목표 단어의 경계가 음운구 경계 안에 포함된 음운구 경계 내 조건에서 상대적으로 유용할 수 있는 인지적 자원이 여유로 워 고빈도를 더 빠르게 처리하는 빈도효과가 나타난 것으로 보 인다. 이러한 결과는 기존의 음운구 경계 내·간의 효과만을 설 명한 선행연구들과 구별되는 점으로써, 단어재인의 주요 변인 인 빈도 변인이 운율정보 처리와 같은 층위에서 서로 영향을 주 고받는 것을 확인할 수 있었다.

\section{References}

Assadollahi, R., \& Pulvermuller, F. (2001). Neuromagnetic evidence for early access to cognitive representations. Neuroreport, 12(2), 207-213.

Assadollahi, R., \& Pulvermuller, F. (2003). Early influences of word length and frequency: A group study using MEG. Neuroreport, 14(8), 1183-1187.

Balota, D. A., \& Chumbley, J. I. (1984). Are lexical decisions a good measure of lexical access? The role of word frequency in the neglected decision stage. Journal of Experimental Psychology: Human Perception and Performance, 10(3), 340-357.

Balota, D. A., \& Chumbley, J. I. (1985). The locus of word-frequency effects in the pronunciation task: Lexical access and/or production? Journal of Memory and Language, 24(1), 89-106.

Bell, A., Brenier, J. M., Gregory, M., Girand, C., \& Jurafsky, D.
(2009). Predictability effects on durations of content and function words in conversational English. Journal of Memory and Language, 60(1), 92-111.

Choi, J. Y., Cho, H. S., \& Nam, K. C. (2011). Effect of prosody on the phonological processing of Korean words. Communication Science \& Disorders, 16(4), 614-626.

Christophe, A., Peperkamp, S., Pallier, C., Block, E., \& Mehler, J. (2004). Phonological phrase boundaries constrain lexical access I . Adult data. Journal of Memory and Language, 51(4), 523-547.

Connine, C. M., Titone, D., \& Wang, J. (1993). Auditory word recognition: Extrinsic and intrinsic effects of word frequency. Journal of Experimental Psychology: Learning, Memory, and Cognition, 19(1), 81-94.

Cutler, A., \& Foss, D. J. (1977). On the role of sentence stress in sentence processing. Language and Speech, 20(1), 1-10.

Cutler, A., \& Norris, D. (1988). The role of strong syllables in segmentation for lexical access. Journal of Experimental Psychology: Human Perception and Performance, 14(1), 113-121.

Dahan, D., Magnuson, J. S., \& Tanenhaus, M. K. (2001). Time course of frequency effects in spoken-word recognition: Evidence from eye movements. Cognitive Psychology, 42(4), 317-367.

Foster, K. I. (1976). Accessing the mental lexicon. New Approaches to Language Mechanisms, 257-287.

Frazier, L., \& Fodor, J. D. (1978). The sausage machine: A new two-stage parsing model. Cognition, 6(4), 291-325.

Gout, A., Christophe, A., \& Morgan, J. L. (2004). Phonological phrase boundaries constrain lexical access II. Infant data. Journal of Memory and Language, 51(4), 548-567.

Hauk, O., \& Pulvermuller, F. (2004). Effects of word length and frequency on the human event-related potential. Clinical Neurophysiology, 155(5), 1090-1103.

Hauk, O., Davis, M. H., Ford, M., Pulvermuller, F., \& Marslen-Wilson, W. D. (2006). The time course of visual word recognition as revealed by linear regression analysis of ERP data. Neuroimage, 30(4), 1383-1400.

Jescheniak, J. D., \& Levelt, W. J. (1994). Word frequency effects in speech production: Retrieval of syntactic information and of phonological form. Journal of Experimental Psychology: Learning, Memory, and Cognition, 20(4), 824.

Jun, S. A. (2000). K-ToBI (Korean ToBI) labelling conventions. Version 3.1. Retrieved from https://linguistics.ucla.edu/people/jun/ktobi/k -tobi.html

Jusczyk, P. W., Houston, D. M., \& Newsome, M. (1999). The beginnings of word segmentation in English-learning infants. Cognitive Psychology, 39(3-4), 159-207.

Kim, S., \& Cho, T. (2009). The use of phrase-level prosodic information in lexical segmentation: Evidence from word-spotting experiments in Korean. Journal of Acoustical Society of America, 
125(5), 3373-3386.

Lee, S. H., Shin, J., Kim, B. Y., \& Lee, Y. J. (2003). Some considerations on SiTEC segmental and prosodic labeling convention for Korean. Malsori, 46, 127-143.

Männel, C., \& Friederici, A. D. (2009). Pauses and intonational phrasing: ERP studies in 5-month-old German infants and adults. Journal of Cognitive Neuroscience, 21(10), 1988-2006.

McClelland, J. L., \& Elman, J. L. (1986). The TRACE model of speech perception. Cognitive Psychology, 18(1), 1-86.

McClelland, J. L., \& Rumelhart, D. E. (1981). An interactive activation model of context effects in letter perception: I. An account of basic findings. Psychological Review, 88(5), 375-407.

Monsell, S. (2012). The nature and locus of word frequency effects in reading. In Basic processes in reading (pp. 148-197). London: Routledge.

Monsell, S., Doyle, M. C., \& Haggard, P. N. (1989). Effects of frequency on visual word recognition tasks: Where are they? Journal of Experimental Psychology: General, 118(1), 43-71.

Morton, J. (1969). Interaction of information in word recognition. Psychological Review, 76(2), 165.

Nan, Y., Knosche, T. R., \& Friederici, A. D. (2009). Non-musicians' perception of phrase boundaries in music: A cross-cultural ERP study. Biological Psychology, 82(1), 70-81.

Nazzi, T., Iakimova, G., Bertoncini, J., Fredonie, S., \& Alcantara, C. (2006). Early segmentation of fluent speech by infants acquiring French: Emerging evidence for crosslinguistic differences. Journal of Memory and Language, 54(3), 283-299.

Polich, J., \& Donchin, E. (1988). P300 and the word frequency effect. Electroencephalography and Clinical Neurophysiology, 70(1), $33-45$.

Ralston, J. V., Pisoni, D. B., Lively, S. E., Greene, B. G., \& Mullennix, J. W. (1991). Comprehension of synthetic speech produced by rule: Word monitoring and sentence-by-sentence listening times. Human Factors, 33(4), 471-491.

Rubenstein, H., Garfield, L., \& Millikan, J. A. (1970). Homographic entries in the internal lexicon. Journal of Verbal Learning and Verbal Behavior, 9(5), 487-494.

Rugg, M. D. (1990). Event-related brain potentials dissociate repetition effecs of high- and low-frequency words. Memory and Cognition, 18(4), 367-379.

Schvaneveldt, R. W., \& McDonald, J. E. (1981). Semantic context and the encoding of words: Evidence for two modes of stimulus analysis. Journal of Experimental Psychology: Human Perception and Performance, 7(3), 673-687.

Sereno, S. C., Rayner, K., \& Posner, M. I. (1998). Establishing a time-line for word recognition: Evidence from eye movements and event-related potentials. Neuro Report, 9(10), 2195-2200.

Shields, J. L., McHugh, A., \& Martin, J. G. (1974). Reaction time to phoneme targets as a function of rhythmic cues in continuous speech. Journal of Experimental Psychology, 102(2), 250-255.

Shin, J. (2011). Korean phonetics and phology. Seoul: Pagijong.

Smith, M., \& Halgren, E. (1987). Event-related potentials during lexical decision: Effects of repetition, word frequency, pronouncebaility, and concreteness. Electroencephalography Clinical Neurophysioogy, 40, 417-421.

Tyler, L. K. (1989). Syntactic deficits and the construction of local phrases in spoken language comprehension. Cognitive Neuropsychology, 6(3), 333-355.

Tyler, L. K., \& Warren, P. (1987). Local and global structure in spoken language comprehension. Journal of Memory and Language, 26(6), 638-657.

Van Petten, C., \& Kutas, M. (1990). Interaction between sentence context and word frequency in event-related brain potentials. Memory and Cognition, 18(4), 380-393.

Zhao, J., Guo, J., Zhou, F., \& Shu, H. (2011). Time course of Chinese monosyllabic spoken word recognition: Evidence from ERP analyses. Neuropsychologia, 49(7), 1761-1770.

\section{- 김제홍 (Jeahong Kim)}

고려대학교 심리학과 박사과정

서울시 성북구 안암로 145

Tel: 02-3290-2548

Email: interkgb@korea.ac.kr

관심분야: 단어재인

\section{• 신하선 (Hasun Shin)}

고려대학교 심리학과 석사과정

서울시 성북구 안암로 145

Tel: 02-3290-2548

Email: hahahasony@naver.com

관심분야: 단어재인

\section{- 김예슬 (Yeseul Kim)}

고려대학교 국어국문학과 석사과정

서울시 성북구 안암로 145

Tel: 02-3290-2505

Email: blossomy21@naver.com

관심분야: 음성학, 음운론

\section{- 윤광열 (Gwangyeol Yun)}

고려대학교 국어국문학과 석사과정

서울시 성북구 안암로 145

Tel: 02-3290-2505

Email: yoon85318@korea.ac.kr

관심분야: 음성학, 음운론 


\section{- 김다슬 (Daseul Kim)}

고려대학교 국어국문학과 석사과정

서울시 성북구 안암로 145

Tel: 02-3290-2505

Email: joyerds@naver.com

관심분야: 음성학, 음운론

- 신지영 (Jiyoung Shin) 교신저자

고려대학교 국어국문학과 교수

서울시 성북구 안암로 145

Tel: 02-3290-1973

Email: shinjy@korea.ac.kr

관심분야: 음성학, 음운론

- 남기춘 (Kichun Nam) 교신저자

고려대학교 심리학과 교수

서울시 성북구 안암로 145

Tel: 02-3290-2548

Email: kichun@korea.ac.kr

관심분야: 단어재인 


\section{부록 1. 실험 자극}

1.1. 실험자극

<고빈도>

이사회의 반대 표명이 있었다. (목표단어: 대표)

요즘 인기 있는 생존 재난 만화다. (존재)

일하는 것을 보아하니 기업 체질이다. (업체)

사무원 정 규 모집이 시작되었다. (규모)

제목표시는 검은색으로 해야 한다. (목표)

발바닥 티눈 치료로 고생이다. (눈치)

기말과제 안내문을 추가 게시하였다. (가게)

동자승에게 한글 염 불 교육을 하였다. (불교)

모의 경 매 체험은 강당에서 진행된다. (매체)

보험사의 지급 보중 거부가 논란이다. (증거)

저것이 주목 받는 신규 제품이다. (규제)

전근 처리가 늦어져 문제이다. (근처)

장미꽃이 바위 주위에 피었다. (위주)

과학 전문 서적은 취급하지 않는다. (문서)

동전 투입 방식의 공중전화도 있었다. (전투)

성과 점 검 토론회가 다음 주에 열린다. (검토)

그는 진정한 천재 무용가이다. (재무)

수비 전 담 배구 선수라 키도 크고 팔도 길다. (담배)

마지막 방법은 신용 보증 대출이다. (증대)

여기는 제빵 전문 체험장이다. (문체)

<저빈도>

세뱃돈은 항상 우리 엄마차지였다. (마차)

태양열 집열판이 지 붕 대신이다. (붕대)

일요일 경마 취소로 원성이 자자하다. (마취)

음악 표절 규제는 문화 보호가 목적이다. (절규)

수제 보석을 할인하여 판매한다. (제보)

그 책이 다루는 때는 문 명 태동기이다. (명태)

휴가 차원으로 하와이에 다녀왔다. (가차)

소득 표시는 굵은 글씨로 한다. (득표)

아버지는 지금 위 염 치료 중이다. (염치)

여기 주변 태권도장은 아주 넓다. (변태)

운전 시 좌우표지판을 살펴 본다. (우표)

임대 계약 변경 내역을 확인하였다. (경내)

천주교도는 추석에 성묘 미사를 한다. (묘미)

국가 차원의 응 징 조치가 필요한 때이다. (징조)

문제는 카드 가 맹 수수료이다. (맹수)

통계학 기본 체계 기술이 알기 쉽게 되어 있다. (본체)

조카가 유아 씨름 대회에 출전한다. (아씨)

최고 인기 메뉴는 모듬 해물 꼬치이다. (물꼬)

이 책이 기본 토대가 될 것이다. (본토)

핀란드의 평 등 교육을 알아본다. (등교)
2.2. 통제자극

경포 바다를 보며 쉴 수 있는 펜션이다. (바다)

쫀득한 반시는 우리 동네특산물이다. (동네)

번화가에서 유사 종교의 포교 활동이 극성이다. (종교)

경찰이 정치 범죄소탕에 주목하였다. (범죄)

불의를 마주하면 강한 분노가 들끓는다. (분노)

열무김차는 여름에 먹어야 제 맛이다. (김치)

흑인 노예해방 운동이 인권의식을 고취시켰다. (노예)

매부 같은 아들 바보는 어디에도 없다. (바보)

기내 온도가 너무 낮아 담요 요청이 쇄도하였다. (온도)

건설사간 경쟁이 건물 붕괴를 초래하였다. (붕괴)

손바닥 너비의 핸드폰으로 못하는 게 없다. (너비)

갑자기 상냥하던 그의 어투가 달라졌다. (어투)

오히려 양반의 권세는 그대로 유지됐다. (권세)

사내들이 쉬지 않고 얼음 냉수를 들이킨다. (냉수)

모든 사람은 임시 낭패를 겪을 수 있다. (낭패)

한 치 오차도 없도록 철저하게 계산했다. (오차)

민석이는 혼전 동거를 하기로 결정했다. (동거)

안동삼베수의는 명품으로 취급된다. (삼베)

길거리 좌판에서 한 해 운세를 점쳤다. (운세)

기아 문제 해결은 최대 난제가 틀림없다. (난제)

3.3. 방해자극

연구를 하는 것에 매진하고 있다. (소리)

이러한 방법을 연구하고 싶다. (정도)

대화하는 청자들을 즐겁고 기쁘게 한다. (상태)

자신감은 경험을 확장하고 발전시킨다. (경우)

아주 최악이라고 느껴져 슬펐다. (여자)

바보 같은 느낌에 대해서 고민한다. (남자)

그러고는 놀라운 일이 일어났다. (이유)

사람은 모든 것을 해내지 못한다. (시대)

완벽주의는 나중에 지치고 힘들어진다. (요소)

자신 있게 문제들에 질문하고 답한다. (나이)

영어가 모국어가 아니지만 잘한다. (아이)

먼저 언젠가는 그것이 끝날 것이다. (친구)

인생은 마라톤 같이 힘들지만 보람차다. (기대)

이것은 진부하고 나도 인정한다. (나무)

경기를 뛴 축구선수들의 평가에 관여한다. (시기)

인류 역사상 위대한 영웅이 등장했다. (가치)

미군이 인천에 어렵게 상륙했다. (거리)

전통이 지금도 이어지고 전해진다. (점수)

나중에는 완전히 폐쇄된 공간이었다. (소녀)

연산된 이미지는 다음과 같이 출력된다. (기여)

배열을 입력하는 명령어를 작성한다. (정치)

다음과 같이 튜플 형식으로 조회된다. (머리)

에디터를 열고 다음 코드를 입력한다. (태도)

활성화 함수는 은닉층과 다르다. (장소)

시각 장면의 맥락을 활용할 수 있다. (도시) 
단정하지 못한 복장을 하고 있었다. (이치) 머릿속에 떠오르는 수가 종종 있다. (정부) 단어 목록들을 잘 기억해냈다. (자리)

하나의 원반만을 이동시킬 수 있다. (고추)

각각 시험대에 오른 경기였다. (사이) 
부록 2. 실험 자극 문장의 음소 레이블링 예시

a. 음운구 경계 내 조건 문장

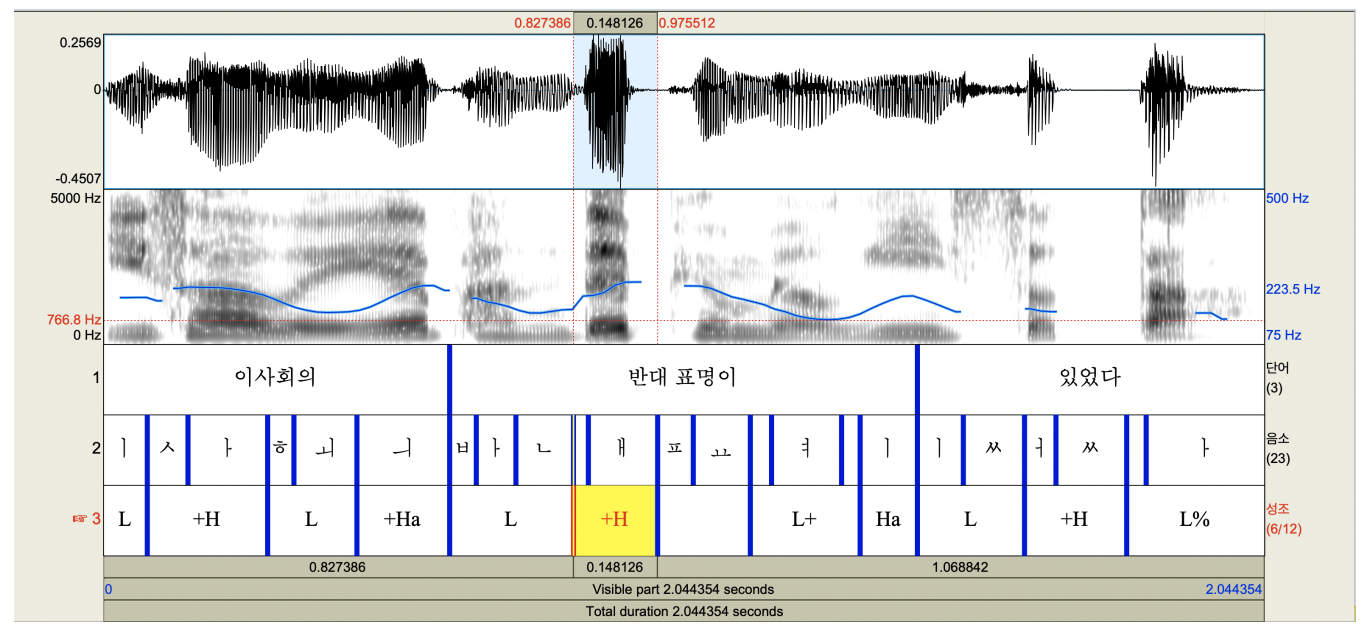

b. 음운구 경계 간 조건 문장

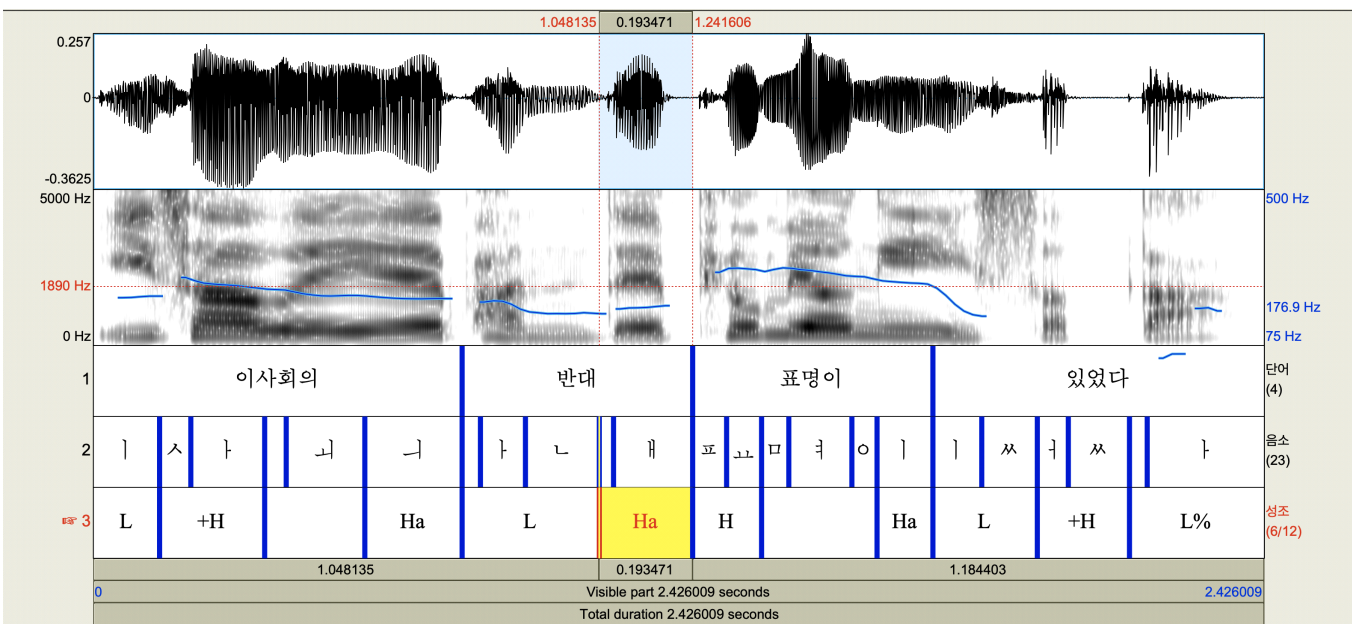

주. H: 고성조, L: 저성조, a: 음운구 수준 경 계, \%: 억양구 수준 경 계, +: 성조의 이어짐.

음소 레이블링은 프랏(6.0.37)을 사용하여 전사하였으며, K-ToBI 기준안(Jun, 2000)을 따랐음. 


\title{
음운구 경계와 단어빈도가 한국어 음운단어 재인에 미치는 영향*
}

\author{
김 제 홍 ${ }^{1}$ 신 하 선 ${ }^{1} \cdot$ 김 예 슬 ${ }^{2}$ 윤 광 열 $\cdot$ 김 다 슬 ${ }^{2} \cdot$ 신 지 영 $^{2}$ 남 기 춘 \\ ${ }^{1}$ 고려대학교 심리학과, ${ }^{2}$ 고려대학교 국어국문학과
}

\begin{abstract}
국문초록
본 연구는 한국어 말소리 단어를 처리할 때, 운율구성성분인 음운구 경계와 어휘변인인 단어빈도가 상호 작용하는 지를 알아보았다. 이를 위해 4개의 음운구로 발화된 문장에서 참가자가 목표단어를 찾을 때, 음운구 경계에 걸침 유무에 따라서 생기는 방해효과를 단어찾기 과제(word monitoring task)를 통해서 조사하였다. 목표단어는 2음절의 고빈도와 저빈도 단어들이 실험자 내 조건으로, 4 개의 음운구로 발화된 문장에서 각각 음운구 경계 간(목표단어: 대표, 음운구 경계: [이사회의] [반대] [표명이] [있었다]) 조건과 음운구 경계 내(목표단어: 마차, 음운구 경계: [세뱃 돈은] [항상] [우리] [엄마 차지였다]) 조건이 실험자 간 조건으로 설계되었다. 실험 결과, 두 변인 중 음운구 경계의 주 효과가 유의미하였으며, 상호작용도 유의미하였다. 사후분석 결과 음운구 경계 내 그룹에서만 고빈도 목표단어 를 저빈도 목표단어보다 유의미하게 빠르게 탐색하는 것으로 나타났고 음운구 경계 간 그룹에서는 목표단어의 빈 도효과가 나타나지 않았다. 이 결과를 기반으로 음운 단어재인시 단어의 빈도변인이 초기 단계에 영향을 미치는 여부와 한국어 말소리 처리에서 두 변인의 중요성을 논의하였다.
\end{abstract}

핵심어: 음운단어 재인, 음운구, 빈도효과

\section{참고문헌}

신지영(2011). 한국어의 말소리. 서울: 박이정.

이숙향, 신지영, 김봉완, 이용주(2003). 음성 코퍼스 구축을 위한 $\mathrm{SiTEC}$ 분절음·운율 레이블링 기준의 검토 및 제안. 말소리, 46, 127-143.

최지연, 조혜숙, 남기춘(2011). 한국어의 운율정보가 음운단어 탐 색에 미치는 영향. 언어청각장애연구, 16(4), 614-626.

\footnotetext{
* 본 연구는 과학기술정보통신부 및 정보통신기술진흥센터의 대학ICT연구센터육성지원사업의 연구결과로 수행되었음(IITP-2019-2017-0-01630).
} 